\title{
Molecular detection of vector borne pathogens in anemic and thrombocytopenic dogs in southern Brazil
}

\author{
Detecção molecular de patógenos transmitidos por vetores em cães anemicos e trombocitopenicos \\ no Sul do Brasil \\ Anna Cláudia Baumel Mongruel ${ }^{1}$; Priscila Ikeda ${ }^{2}$; Keyla Carstens Marques de Sousa ${ }^{2}$; Jyan Lucas Benevenute ${ }^{2}$; \\ Margarete Kimie Falbo ${ }^{3}$; Rosangela Zacarias Machado ${ }^{2}$; Adriano de Oliveira Torres Carrasco ${ }^{4}$; \\ Marcos Rogério Andréz; Meire Christina Seki ${ }^{4 *}$

\begin{abstract}
${ }^{1}$ Laboratório de Zoonoses e Epidemiologia Molecular, Universidade Federal do Paraná - UFPR, Curitiba, PR, Brasil
${ }^{2}$ Laboratório de Imunoparasitologia, Departamento de Patologia Veterinária, Faculdade de Ciências Agrárias e Veterinárias, Universidade Estadual Paulista - UNESP, Jaboticabal, SP, Brasil

${ }^{3}$ Laboratório de Patologia Clínica, Departamento de Medicina Veterinária, Universidade Estadual do Centro-Oeste - UNICENTRO, Guarapuava, PR, Brasil

${ }^{4}$ Laboratório de Doenças Infecciosas e Parasitárias, Departamento de Medicina Veterinária, Universidade Estadual do Centro-Oeste UNICENTRO, Guarapuava, PR, Brasil
\end{abstract}

Received June 8, 2018

Accepted August 22, 2018

\begin{abstract}
Arthropod-borne pathogens are medically important because of their ability to cause diseases in their hosts. The purpose of this study was to detect the occurrence of Ehrlichia spp., piroplasmids and Hepatozoon spp. in dogs with anemia and thrombocytopenia in southern Brazil. EDTA-whole blood was collected from 75 domestic dogs presenting anemia or/and thrombocytopenia from Guarapuava, state of Paraná, Brazil. DNA samples were subjected to conventional PCR assays for Ehrlichia spp. (dsb), piroplasmids (18S rRNA) and Hepatozoon spp. (18S rRNA), followed by sequencing and phylogenetic analyses. Among the 75 dogs, one (1.33\%) was positive for Hepatozoon sp. and six (8\%) were positive for piroplasmids in $18 \mathrm{~S}$ rRNA cPCR assays. None of the dogs showed positive results in Ehrlichia spp.-cPCR targeting dsb gene. The phylogenetic analyses revealed that three piroplasm sequences were clustered with Rangellia vitalii, while one sequence was grouped with B. vogeli. The only sequence obtained from Hepatozoon spp.-PCR protocol was pooled with $H$. canis. Therefore, there is urgent need for differential molecular diagnosis of the two piroplasm species cited as etiological agents in clinical cases of canine hemoparasitic diseases, given the higher pathogenic potential of $R$. vitalii than of $B$. vogeli.
\end{abstract}

Keywords: Babesia vogeli, Rangelia vitalii, Hepatozoon canis, phylogenetic analysis, tick borne diseases.

\section{Resumo}

Agentes transmitidos por artrópodes têm grande importância na medicina veterinária devido à sua capacidade de causar doenças graves em seus hospedeiros. O presente estudo objetivou investigar a ocorrência de três patógenos transmitidos por vetores, Ehrlichia canis, Rangelia vitalii e Hepatozoon canis, em cães na região sul do Brasil. Foram coletadas amostras de sangue total de 75 cães domésticos que apresentavam anemia e/ou trombocitopenia, em Guarapuava, Paraná, Brasil. As amostras de DNA foram submetidas à técnica de PCR convencional para E. canis (dsb), piroplasmídeos (18S rRNA) e Hepatozoon spp. (18S rRNA), seguida de sequenciamento e análises filogenéticas. Das 75 amostras, uma (1,33\%) foi positiva para Hepatozoon spp. e seis $(8 \%)$ foram positivas para Babesia spp. Nenhuma amostra mostrou resultados positivos para Ehrlichia spp. utilizando a detecção pelo gene $d s b$. As análises filogenéticas revelaram que três sequências obtidas foram agrupadas no mesmo clado que $R$. vitalii, enquanto uma foi agrupada juntamente com $B$. vogeli. A única sequência obtida pelo protocolo de PCR para Hepatozoon spp. foi agrupada juntamente com H. canis. Assim, é justificada necessidade de diferenciação das espécies de piroplasmas, através do diagnóstico molecular, como agentes etiológicos nos casos clínicos de hemoparasitose canina, considerando o potencial patogênico de $R$. vitalii quando comparado à $B$. vogeli.

Palavras-chave: Babesia vogeli, Rangelia vitalii, Hepatozoon canis, análise filogenética, doenças transmitidas por carrapatos.

${ }^{*}$ Corresponding author: Meire Christina Seki. Universidade Estadual do Centro-Oeste - UNICENTRO, Rua Simeão Varela de Sá, 03, Vila Carli, CEP 85040-080, Guarapuava, PR, Brasil. e-mail: meireseki@hotmail.com 


\section{Introduction}

Arthropod-borne diseases involve several infectious agents, hosts and vectors, strongly affecting human and animal health (HARRUS \& BANETH, 2005). The geographic distribution of arthropods and vector-borne agents is expanding due to climate, ecological and environmental changes (GRAY et al., 2009). In this context, Anaplasmataceae agents, piroplasmids and Hepatozoon spp. have emerged as important pathogens among domestic animals worldwide (ANDRÉ et al., 2015).

Ehrlichia canis, a widespread tick-borne pathogen among domestic dogs, is considered the primary pathogen responsible for canine monocytic ehrlichiosis (RIKIHISA, 2011). Clinical manifestations of the disease include anemia, fever, weight loss, anorexia, thrombocytopenia and lymphadenopathy (CASTRO et al., 2004; NAKAGHI et al., 2008). Ehrlichia canis has been reported in dogs in several regions in Brazil (DAGNONE et al., 2009; SOUSA et al., 2013; MELO et al., 2016), particularly in tropical and subtropical regions, in accordance with the distribution of its vector, the tropical strain of $R$. sanguineus sensu lato (MORAES-FILHO et al., 2015).

Piroplasmosis, one of the most prevalent vector-borne diseases among animals, is caused by tick-borne protozoan agents that parasitize several wild and domestic vertebrates worldwide (ALVARADO-RYBAK et al., 2016). Piroplasm infections are usually characterized by fever, anemia and hemoglobinuria, and can lead to death in severe cases (KUTTLER, 1988). In Brazil, B. vogeli (PASSOS et al., 2005), Babesia gibsoni (TRAPP et al., 2006) and R. vitalii (SOARES et al., 2011) have been confirmed, by both morphological and molecular methods, to infect dogs. While $R$. sanguineus s.l. is considered the main vector of $B$. vogeli, and a suspected vector of $B$. gibsoni in the country (DANTAS-TORRES, 2008), Amblyomma aureolatum is the vector of $R$. vitalii (SOARES \& GIROTTO SOARES, 2015).

Canine hepatozoonosis is a disease caused by $H$. canis and by Hepatozoon americanum (LAPPIN, 2010). These two agents have distinct clinical, pathological and genetic characteristics. While $H$. canis has a generalized distribution and has been described worldwide, $H$. americanum seems to be narrowly restricted to the United States of America (LAPPIN, 2010; O'DWYER, 2011). In Brazil, $H$. canis and genotypes closely related to $H$. americanum circulate in domestic dogs and wild canids (RUBINI et al., 2005; FORLANO et al., 2007; ANDRÉ et al., 2010; GOMES et al., 2016; MALHEIROS et al., 2016; SOUSA et al., 2017). Although Rhipicephalus sanguineus s.l. is considered the main biological vector of canine hepatozoonosis caused by H. canis (GIANNELLI et al., 2013), preliminary studies in Brazil indicate that the importance of the tick $R$. sanguineus is negligible or absent in the transmission of $H$. canis (DEMONER et al., 2013). Amblyomma ovale has been implicated as the main vector of $H$. canis in rural areas in Brazil (FORLANO et al., 2005; DEMONER et al., 2013).

This study focused on detecting the occurrence of Ehrlichia spp., piroplasmids and Hepatozoon spp. in dogs showing hematological abnormalities suggestive of hemoparasitic diseases (anemia and thrombocytopenia) in southern Brazil, using molecular methods.

\section{Material and Methods}

The blood samples used in this study were collected from 75 dogs presenting anemia (packed cell volume $<37 \%$ ) or/and thrombocytopenia (platelets $<200000$ cells $/ \mathrm{mm}^{3}$ ), as indicated by a complete blood count (CBC) performed on a SDH-3 Vet blood counting machine (Labtest $\left.{ }^{\circ}\right)$. Anemia was observed in 45 dogs, thrombocytopenia in 12 and anemia and thrombocytopenia in 19 animals. The dogs were treated at the School of Veterinary Medicine (CEVET) of the Universidade Estadual do Centro Oeste

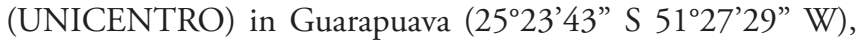
state of Paraná, Brazil, between in 2013 and 2014. The blood samples were deposited in the Sample Repository of the Laboratory of Infectious and Parasitic Diseases of CEVET. This study was approved by the Ethics Committee on Animal Use (CEUA) of UNICENTRO, under Protocol no. 011/2015.

DNA was extracted from $200 \mu \mathrm{L}$ of each whole blood sample, using a commercial kit (QIAmp DNA Blood Mini Kit, Qiagen ${ }^{\mathrm{TM}}$ ), as recommended by the manufacturer. The quality and concentration of extracted DNA was analyzed spectrophotometrically using a Thermo Scientific ${ }^{\mathrm{TM}}$ NanoDrop spectrophotometer, based on an evaluation of the absorbance of each sample. The extracted DNA samples were identified and stored at $-20^{\circ} \mathrm{C}$ until use.

A previously described protocol was performed targeting a $378 \mathrm{pb}$ fragment of $d s b$ gene to detect Ehrlichia spp. DNA. To this end, primers Dsb-330 and Dsb-728 and thermocycler protocols described in Table 1 are used (DOYLE et al., 2005). The total volume of the reaction was $25 \mu \mathrm{L}$, comprising $5 \mu \mathrm{L}$ of DNA, $0.2 \mathrm{mM}$ dNTPs (Invitrogen, Carlsbad, USA), $2.5 \mathrm{mM} \mathrm{MgCl}{ }_{2}$ (Invitrogen, Carlsbad, USA), 1 pmol of each primer (Invitrogen, Carlsbad, USA), of buffer 10x (Invitrogen, Carlsbad, USA), $1.25 \mathrm{U}$ of Taq DNA Polymerase (Invitrogen, Carlsbad, USA) and ultrapure sterile water (Invitrogen, Carlsbad, USA) q.s.p. Ehrlichia canis DNA (SOUSA et al., 2013) and ultrapure sterile water (Promega), respectively, were used as positive and negative controls.

A nested PCR assay protocol targeting $18 \mathrm{~S}$ rRNA gene was performed in order to detect piroplasm DNA (JEFFERIES et al., 2007). Primers sequences and thermocycler protocol are described in Table 1 . The final volume of the reaction was $25 \mu \mathrm{L}$ containing $5 \mu \mathrm{L}$ of DNA, $0.2 \mathrm{mM}$ dNTPs (Invitrogen, Carlsbad, USA), 0.5 $\mu \mathrm{M}$ of each primer (Invitrogen, Carlsbad, USA), $1.5 \mathrm{mM} \mathrm{MgCl}_{2}$ (Invitrogen, Carlsbad, USA), 0.75U Taq DNA polymerase (Invitrogen, Carlsbad, USA), buffer and ultrapure sterile water (Invitrogen, Carlsbad, USA) q.s.p. $25 \mu \mathrm{L}$. Babesia vogeli DNA (SOUSA et al., 2013) and sterile ultrapure water (Promega) were used as positive and negative controls, respectively.

Two different protocols based on $18 \mathrm{~S}$ rRNA were performed in order to detect Hepatozoon spp. (PERKINS \& KELLER, 2001; UJVARI et al., 2004). Primers sequences and thermocycler protocols are described in Table 1 . The reactions involved a total volume of $25 \mu \mathrm{L}$, consisting of $5 \mu \mathrm{L}$ of DNA, $0.2 \mathrm{mM}$ dNTP (Invitrogen, Carlsbad, USA), $1 \mu \mathrm{M}$ of each primer (Invitrogen, Carlsbad, USA), $1.0 \mathrm{mM} \mathrm{MgCl}_{2}$ (Invitrogen, Carlsbad, USA), 1 U Taq DNA Polymerase (Invitrogen, Carlsbad, USA), buffer and ultrapure sterile water (Invitrogen, Carlsbad, USA) q.s.p. $25 \mu \mathrm{L}$. 
Table 1. Primer sequences, thermocycler conditions and references utilized for each target pathogen.

\begin{tabular}{|c|c|c|c|}
\hline Pathogen & Primers & Cycles & References \\
\hline $\begin{array}{l}\text { Ehrlichia spp. } \\
\text { (dsb gene) }\end{array}$ & $\begin{array}{l}\text { Dsb-330 5’- GATGATGTCTGAAGATATGAAACAAAT-3' } \\
\text { Dsb-728 5’- CTGCTCGTCTATTTTACTTCTTAAAGT-3' }\end{array}$ & $\begin{array}{l}\text { Initial denaturation at } 95^{\circ} \mathrm{C} \text {; } \\
50 \text { cycles: } 94^{\circ} \mathrm{C} \text { for } 15 \mathrm{~s}, 58^{\circ} \mathrm{C} \\
\text { for } 30 \mathrm{~s}, 72^{\circ} \mathrm{C} \text { for } 30 \mathrm{~s} \text { and } 72{ }^{\circ} \mathrm{C} \\
\text { for } 5 \mathrm{~min} \text {. }\end{array}$ & $\begin{array}{l}\text { Doyle et al. } \\
(2005)\end{array}$ \\
\hline $\begin{array}{l}\text { Piroplasm DNA } \\
\text { (18S rRNA gene) }\end{array}$ & $\begin{array}{l}\text { BTF1 5'-GGCTCATTACAACAGTTATAG-3' } \\
\text { BTR1 5'-CCCAAAGACTTTGATTTCTCTC-3' } \\
\text { BTF2 5'-CCGTGCTAATTGTAGGGCTAATAC-3' } \\
\text { BTR2 5'-GGACTACGACGGTATCTGATCG-3' }\end{array}$ & $\begin{array}{l}94^{\circ} \mathrm{C} \text { for } 3 \mathrm{~min} ; 58{ }^{\circ} \mathrm{C} \text { for } 1 \mathrm{~min} \text {; } \\
72^{\circ} \mathrm{C} \text { for } 2 \mathrm{~min} ; 45 \text { cycles: } 94 \\
{ }^{\circ} \mathrm{C} \text { for } 30 \mathrm{sec}, 58{ }^{\circ} \mathrm{C} \text { for } 20 \mathrm{sec} \text {, } \\
72{ }^{\circ} \mathrm{C} \text { for } 30 \mathrm{sec}, 72{ }^{\circ} \mathrm{C} \text { for } 7 \mathrm{~min} . \\
\text { Annealing temperature } 62^{\circ} \mathrm{C} \text { in } \\
\text { the second reaction. }\end{array}$ & $\begin{array}{l}\text { Jefferies et al. } \\
\qquad(2007)\end{array}$ \\
\hline $\begin{array}{l}\text { Hepatozoon spp. } \\
\text { (18S rRNA gene) }\end{array}$ & $\begin{array}{l}\text { HEMO1 5'-TATTGGTTTTAAGAACTAATTTTATGATTG-3' } \\
\text { HEMO2 5'-CTTCTCCTTCCTTTAAGTGATAAGGTTCAC-3' }\end{array}$ & $\begin{array}{l}94^{\circ} \mathrm{C} \text { for } 3 \mathrm{~min}, 35 \text { cycles: } 94^{\circ} \mathrm{C} \\
\text { for } 45 \mathrm{~s}, 60^{\circ} \mathrm{C} \text { for } 1 \mathrm{~min}, 72^{\circ} \mathrm{C} \\
\text { for } 1 \mathrm{~m}, 72^{\circ} \mathrm{C} \text { for } 7 \mathrm{~min} .\end{array}$ & $\begin{array}{l}\text { Perkins \& } \\
\text { Keller (2001); } \\
\text { O’Dwyer et al. } \\
\text { (2013) }\end{array}$ \\
\hline $\begin{array}{l}\text { Hepatozoon spp. } \\
\text { (18S rRNA gene) }\end{array}$ & $\begin{array}{l}\text { HepF300 5’-GTTTCTGACCTATCAGCTTTCGACG-3’ } \\
\text { Hep900 5’-CAAATCTAAGAATTTCACCTCTGAC-3’ }\end{array}$ & $\begin{array}{l}94^{\circ} \mathrm{C} \text { for } 3 \mathrm{~min}, 35 \text { cycles: } 94^{\circ} \mathrm{C} \\
\text { for } 45 \mathrm{~s}, 56^{\circ} \mathrm{C} \text { for } 1 \mathrm{~min}, 60^{\circ} \mathrm{C} \\
\text { for } 1 \mathrm{~m}, 72^{\circ} \mathrm{C} \text { for } 7 \mathrm{~min} .\end{array}$ & $\begin{array}{l}\text { Ujvari et al. } \\
\text { (2004) }\end{array}$ \\
\hline
\end{tabular}

These two different PCR protocols were used to amplify different regions of the 18S rRNA gene of Hepatozoon spp. in order to obtain a large $18 \mathrm{~S}$ rRNA fragment $(1300 \mathrm{pb})$ to be used in phylogenetic analyses. Hepatozoon canis DNA (SOUSA et al., 2017) and sterile ultrapure water (Promega) were used as positive and negative controls, respectively.

The amplified products were subjected to electrophoresis with ethidium bromide $(0.5 \mu \mathrm{L} / \mathrm{mL})-1 \%$ agarose gel stain in TBE running buffer, $\mathrm{pH} 8.0$ (44.58 M Tris-base; $0.44 \mathrm{M}$ boric acid; and $12.49 \mathrm{mM}$ EDTA), at $90 \mathrm{~V} / 150 \mathrm{~mA}$ for 60 minutes. The length of the amplified products was determined by means of a $100 \mathrm{pb}$ marker (Life Technologies ${ }^{\mathrm{TM}}$ ). The results were examined and analyzed under an UV light transilluminator (ChemiDoc ${ }^{\text {тм }}$ MP Imaging System, Bio $\left.\operatorname{Rad}^{\mathrm{TM}}\right)$. Amplicons were purified using a Silica Bead DNA Gel Extraction Kit (Fermentas, São Paulo, SP), following the manufacturer's recommendations.

Purified amplicons were sequenced using an automated method based on chain termination by dideoxynucleotides (SANGER et al., 1977) in an ABI PRISM 3700 DNA Analyzer (Applied Biosystems ${ }^{\mathrm{TM}}$ ). After sequencing, the electropherograms were analyzed using BioEdit v. 7.0.5.3 (HALL, 1999) software and then subjected to a screening test using Phred-Phrap-Consed version 23 software (EWING \& GREEN, 1998; EWING et al., 1998) to evaluate the quality if the electropherograms and obtain consensus sequences from the alignment of sense and antisense sequences. The sequences were analyzed using the BLAST program (ALTSCHUL et al., 1990) to compare them with sequences retrieved from the GenBank database.

The sequences were aligned using the ClustalW software (THOMPSON et al., 1994) via BioEdit v. 7.0.5.3 (HALL, 1999). Maximum Likelihood (ML) analyses were performed using the W-IQ-Tree tool available online (TRIFINOPOULOS et al., 2016), with the node support evaluated by means of 1000 bootstrap repetitions (FELSENSTEIN, 1985). The Bayesian inference (BI) analysis was performed using the MrBayes 3.2.2 program on XSEDE (RONQUIST \& HUELSENBECK, 2003) via the
CIPRES Science Gateway (MILLER et al., 2010). Markov Chain Monte Carlo (MCMC) simulations were run for $10^{6}$ generations with a sampling frequency of every 100 generations and a burn-in of $25 \%$. The best model of evolution was selected by means of the jModelTest2 (version 2.1.6) program on XSEDE (DARRIBA et al., 2012), under the Akaike Information Criterion (AIC) and Bayesian Information Criterion (BIC) (POSADA \& BUCKLEY, 2004). The phylogenetic trees were edited using TreeGraph 2.0.56-381 beta software (STOVER \& MULLER, 2010) and rooting at the outgroup chosen for each parasite. Bootstrap and posterior probability values lower than $50 \%$ are not considered relevant by the test, and are therefore not shown.

\section{Results}

Among the 75 canine blood samples that were evaluated, $18 \mathrm{~S}$ rRNA of Hepatozoon sp. was detected in one sample $(1.33 \%$ $[1 / 75])$, and $18 \mathrm{~S}$ rRNA of piroplasmids was detected in six $(8.0 \%$ [6/75]) samples. None of the samples tested positive in the PCR assay for Ehrlichia spp. based on the $d s b$ gene. The results of clinical signs, hematological abnormalities, ticks infestation, PCR and sequencing results of each positive dog were in Table 2.

Four of the six samples that tested positive for piroplasmids were selected for sequencing, in view of the higher intensity of bands in agarose gel electrophoresis. In an analysis of these four sequences by nBLAST, three showed 99-100\% identity with R. vitalii detected in domestic dogs in Passo Fundo, Rio Grande do Sul (GenBank accession number: KT288200) with 100\% query coverage. On the other hand, a sequence showed $100 \%$ identity with Babesia vogeli sequences detected in dogs sampled in the city of Belém, state of Pará (GenBank accession number: KT333456), and a B. vogeli sequence obtained from a domestic cat in southern Brazil (GenBank accession number: KT323935). The partial sequence of the $18 \mathrm{~S}$ rRNA gene from Hepatozoon sp. 
Table 2. Clinical signs, hematological abnormalities, tick infestation, PCR and sequencing results of each positive dog in PCR assays for piroplasmids and Hepatozoon spp. sampled in the city of Guarapuava, state of Paraná, Southern Brazil.

\begin{tabular}{|c|c|c|c|c|c|}
\hline Animal & Clinical signs & $\begin{array}{l}\text { Hematological } \\
\text { Abnormalities* }\end{array}$ & Infestation by ticks & $\begin{array}{l}\text { PCR results } \\
\text { (18S rRNA) }\end{array}$ & Sequencing results \\
\hline 1 & None & anemia & No & Hepatozoon sp. & H. canis \\
\hline 2 & apathy, anorexia & anemia & No & Piroplasmids & Not sequenced \\
\hline 3 & apathy, anorexia & anemia and thrombocytopenia & No & Piroplasmids & Not sequenced \\
\hline 4 & ear bleeding, apathy & anemia and thrombocytopenia & A. aureolatum & Piroplasmids & R. vitalii \\
\hline 5 & ear bleeding, apathy & anemia and thrombocytopenia & A. aureolatum & Piroplasmids & R. vitalii \\
\hline 6 & apathy & anemia & No & Piroplasmids & R. vitalii \\
\hline 7 & lymphadenomegaly & anemia & No & Piroplasmids & B. vogeli \\
\hline
\end{tabular}

${ }^{*}$ All the blood smears of the dogs contained Howell-Jolly bodies, but the presence of $R$. vitalii and $B$. vogeli piroplasms and of $H$. canis gametocytes was not observed.

showed 99\% identity with $H$. canis sequences (GenBank accession number: KY026192/KU729737) identified in Brazil.

A similar topology was observed in the cladograms generated by ML and BI analysis. Regarding the analysis of the partial sequences of the $18 \mathrm{~S}$ rRNA gene of piroplasmids, three samples were found to be allocated in a large clade together with $R$. vitalii sequences, while one of the sequences was positioned in a clade together with B. vogeli (Figure 1).

On the other hand, the phylogenetic analysis of the partial sequence of the 18S rRNA gene from Hepatozoon sp. indicated that the sequence obtained in this study was positioned in the same clade as $H$. canis sequences. Hepatozoon americanum sequences formed a monophyletic group apparently unrelated to the sequence obtained in this study (Figure 2).

\section{Discussion}

Given that vector-borne diseases are on the rise worldwide (DANTAS-TORRES et al., 2012), veterinarians should be prepared to diagnose, treat and prevent such infections (DANTAS-TORRES \& OTRANTO, 2016). The city of Guarapuava, where this study was conducted, is located in the midwestern region of the state of Paraná, in southern Brazil. No molecular studies had heretofore been conducted to elucidate the occurrence of vector-transmitted agents in the region.

In this study, 8.0\% (6/75) of the tested animals were positive in PCR assays for piroplasmids based on the 18S rRNA gene. The occurrence of piroplasmids found in this study was also reported by Lemos et al. (2012) (6.8\%) in 103 canine blood samples sent to a clinical laboratory, which, after sequencing of the positive samples, confirmed the presence of $B$. vogeli and $R$. vitalii in Teresópolis, state of Rio de Janeiro, Brazil.

Although rangeliosis in the acute phase is characterized by apathy, anorexia/inappetence and mild to severe jaundice, bloody diarrhea, vomiting and consequent dehydration (FIGHERA et al., 2010), the animals testing positive in this study presented only apathy. The intense ear bleeding observed in two of the positive dogs is well described in cases of rangeliosis. Moreover, bleeding in other sites may also occur, especially in the form of petechiae and suffusions in the skin, oral mucosa and nasal planum (FIGHERA et al., 2010). Anemia with the presence of anisocytosis, polychromasia and Howell-Jolly bodies was found in the CBC of dogs testing positive by PCR for piroplasmids in this study, and such findings are also reported in the literature (FIGHERA, 2007; FIGHERA et al., 2010; FRANÇA et al., 2010; LEMOS et al., 2017). Thrombocytopenia, another frequent finding among dogs positive for $R$. vitalii in this study, has also been reported in dogs with rangeliosis, in response to defects in platelet aggregation associated with impaired release of adenosine diphosphate (ADP) (PAIM et al., 2012; LEMOS et al., 2017). Infestation by $A$. aureolatum, the vector of $R$. vitalii in Brazil (SOARES \& GIROTTO SOARES, 2015), was found in two dogs positive for $R$. vitalii.

The differential diagnosis of rangeliosis and babesiosis by means of molecular techniques is important not only for taxonomic purposes. Although piroplasms are genetically related, differences in the pathogenicity of $R$. vitalii and $B$. vogeli have been identified. While acute conditions are described in $R$. vitalii infection in domestic dogs (LORETTI \& BARROS, 2004; SOARES et al., 2011; FRANÇA et al., 2014), which require therapeutic intervention (SOARES et al., 2011), B. vogeli is usually associated with asymptomatic infections (MALHEIROS et al., 2016). These data corroborate those found in this study, since the animals positive for $R$. vitalii presented acute clinical signs such as anemia, thrombocytopenia, external bleeding and anorexia.

In this study, only one $\operatorname{dog}(1.33 \%)$, which had been run over, tested positive for $H$. canis. The absence of clinical signs has been reported in dogs with hepatozoonosis (SPOLIDORIO et al., 2009). According to Mundim et al. (2008), the clinical presentation of the disease varies according to the level of parasitemia and the immune status of the animal, which, after being run over, would explain the presence of the parasite in the blood. This low occurrence of H. canis is similar to that described by Pereira et al. (2011). Upon evaluating dogs from the peri-urban region of Piraí, state of Rio de Janeiro, the authors detected $H$. canis in two canine blood samples out of a total of 88 samples collected by convenience during an anti-rabies vaccination campaign. In addition, a low prevalence of this pathogen in dogs has also been described in an urban area of the state of Rio Grande do Sul (MALHEIROS et al., 2016). It is believed that the agent occurs more frequently in the rural area because of the greater contact of domestic animals with wild hosts and vectors, where the presence of ticks of the genus Amblyomma is more evident. In contrast, urban dogs are parasitized mainly by 


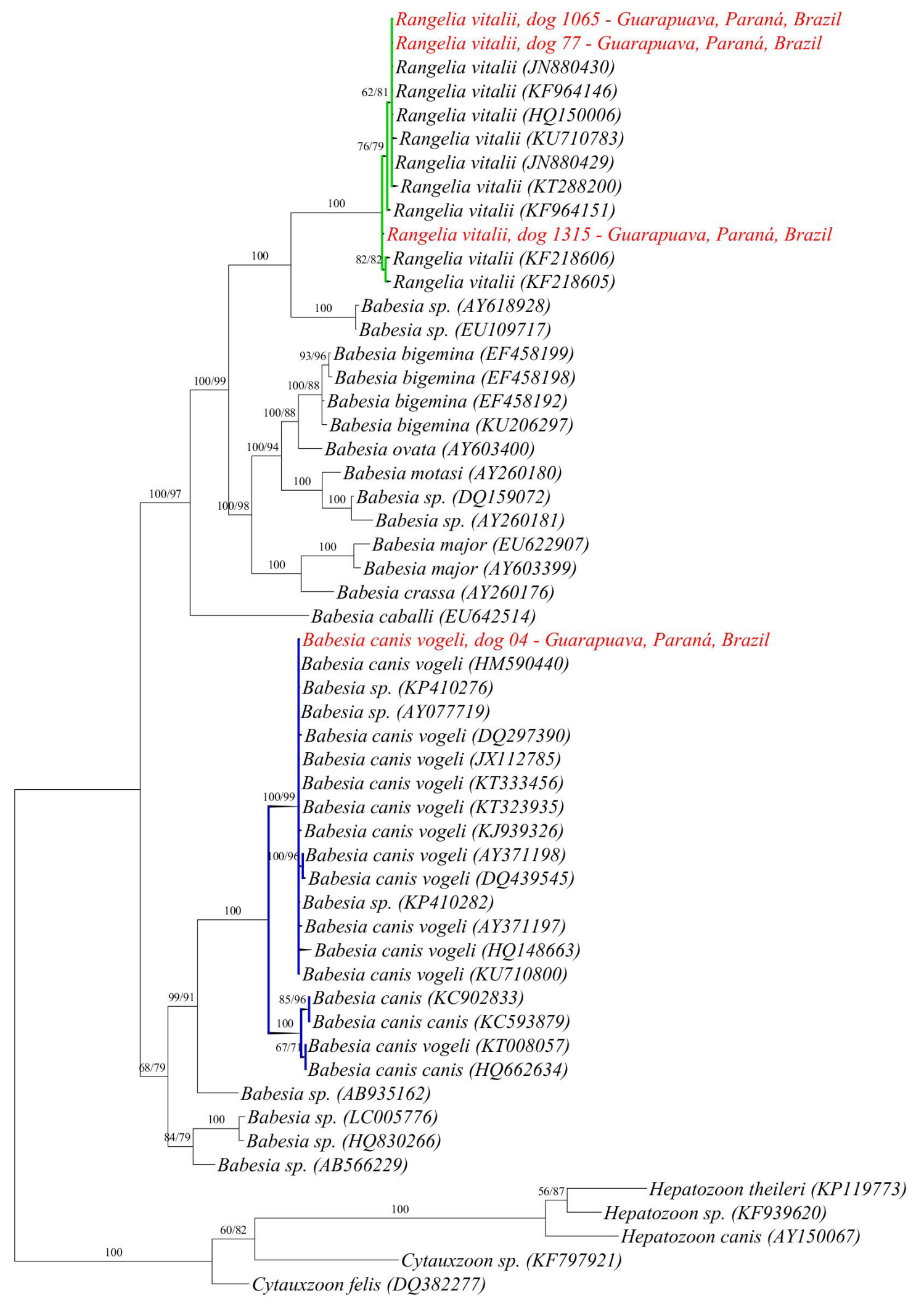

Figure 1. Phylogenetic analysis based on $18 \mathrm{~S}$ rRNA gene of Babesia spp. (1810 bp after alignment). The evolutionary model used here was GTR for the Maximum Likelihood method and TIM2 for Bayesian Inference, both with invariable sites and gamma distribution. The topology presented here is based on Bayesian analysis and shows the posterior probability/bootstrap values in each branch. Monte Carlo Markov Chain (MCMC) simulations were used with $10^{6}$ generations to define the posterior probability and bootstrapping of 1000 replicates. Values above $50 \%$ are shown. The sequences of this study are highlighted in red and separated in two different groups, clustering Rangelia vitalii (green branches) and Babesia canis vogeli (blue branches). Hepatozoon spp. and Cytauxzoon spp. were used as outgroups. 


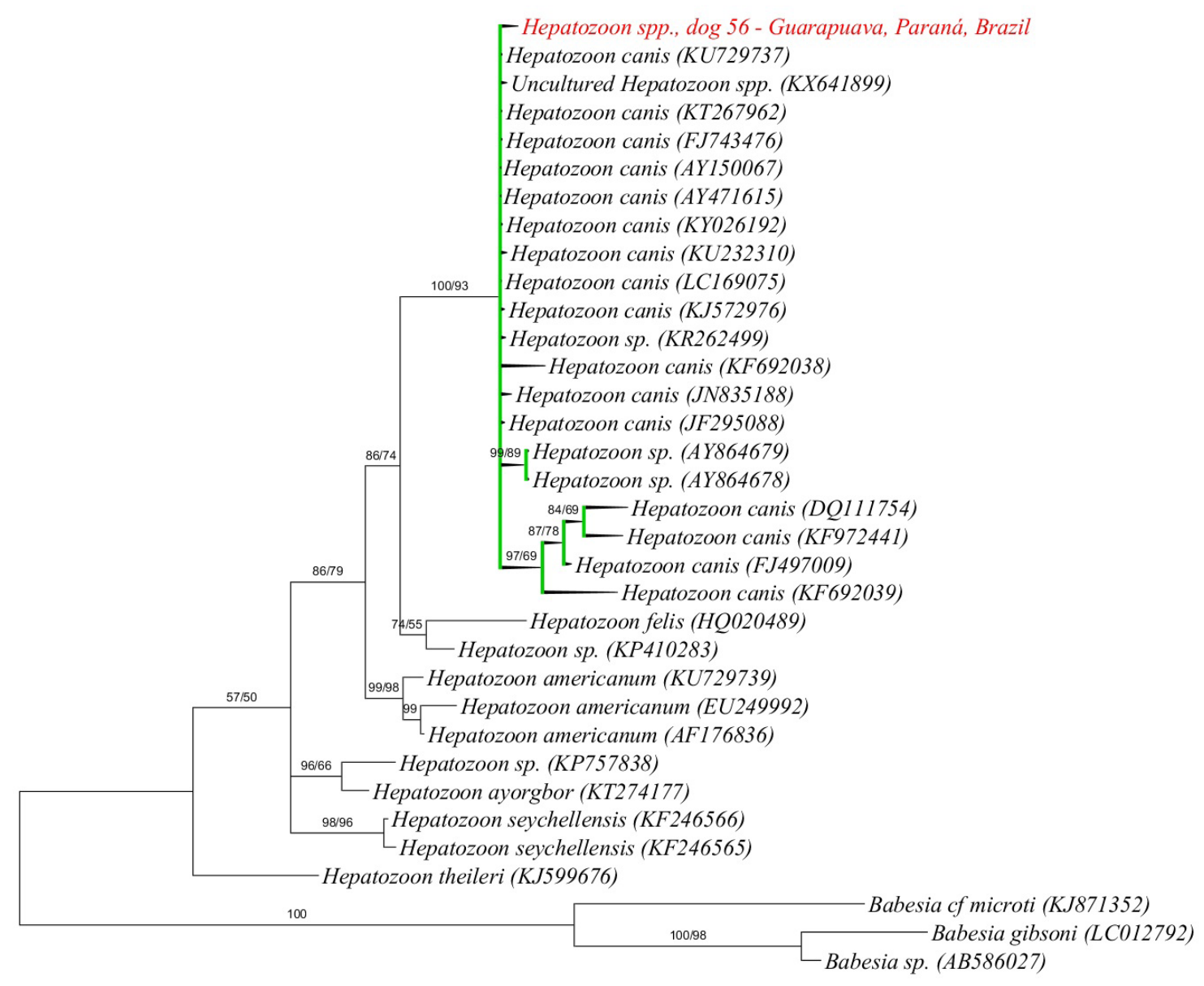

Figure 2. Phylogenetic analysis based on $18 \mathrm{~S}$ rRNA gene of Hepatozoon sp. (1670 bp after alignment). The evolutionary model was TPM2uf with gamma distribution for the Maximum Likelihood method and Bayesian Inference. The topology presented here is based on Bayesian analysis, showing the posterior probability/bootstrap values in each branch. Monte Carlo Markov Chain (MCMC) simulations were used with $10^{6}$ generations to define the posterior probability and bootstrapping of 1000 replicates. Values above $50 \%$ are shown. The sequence of the present work is highlighted in red, clustering as a polyatomic branch with Hepatozoon canis (green branches) with high support value (100/93). Babesia spp. was used as outgroup.

Rhipicephalus sanguineus (O'DWYER et al., 2001), whose vectorial capacity in Brazil still requires further studies (DEMONER et al., 2013). Although $A$. ovale is considered one of the main vectors of H. canis in Brazil (FORLANO et al., 2005; DEMONER et al., 2013), the occurrence of this tick species in domestic dogs in the region of Guarapuava has not been reported to date. Future studies are needed to investigate the vectorial competence of other tick species that transmit $H$. canis, as well as other canine hepatozoonosis transmission routes.

The authors of recent studies have proposed that the taxon Rhipicephalus sanguineus possibly comprises at least two morphologically and genetically distinct strains in the Neotropical region. In addition to the size of ticks, which tend to be smaller in regions close to the equator than ticks found at higher latitudes (SZABÓ et al., 2005; SANCHES et al., 2016), there are differences in vector competence for $E$. canis between these strains, in which only the tropical strain proved to be a competent vector of $E$. canis (MORAES-FILHO et al., 2015). The absence of anemic and thrombocytopenic animals positive by PCR for Ehrlichia sp. in this study may be attributed to the low vector competence of the tick species $R$. sanguineus of the temperate strain that occurs in southern Brazil (NAVA et al., 2015; MORAES-FILHO et al., 2015).

Nakaghi et al. (2010) did not find a significant difference in the results obtained by the $16 \mathrm{~S}$ rRNA amplification protocol by nested PCR and the dsd gene of Ehrlichia by conventional PCR, since a total of $66(69.7 \%)$ positive samples were obtained by the two protocols in their study. However, future studies using more sensitive protocols, such as quantitative real-time PCR, may determine definitively whether or not Ehrlichia is circulating in the area under study.

None of the dogs with hematological alterations sampled in this study showed coinfection by the aforementioned infectious agents. These findings differ from those reported by Spolidorio et al. (2009) in the state of Espírito Santo, Brazil. In their study, all the 20 asymptomatic dogs (21.7\% [20/92]) that tested positive for Babesia sp. were also positive for Hepatozoon spp. In addition, the aforementioned authors found a significant correlation between infestation by $R$. sanguineus ticks and the presence of Hepatozoon sp. 
In the present study, only two animals were infested with Amblyomma aureolatum ticks, and both dogs were only positive for $R$. vitalii. In another study by Spolidorio et al. (2011), out of a total of 15 blood samples from dogs diagnosed with Babesia sp. and/or Hepatozoon sp. infection by direct visualization of parasites in Giemsa-stained blood smears, six tested positive for Babesia sp. and nine for Hepatozoon sp. by means of conventional PCR, and five animals presented coinfection by the two agents,

The region of Guarapuava is marked by an average temperature varying from $18{ }^{\circ} \mathrm{C}$ to $22^{\circ} \mathrm{C}$, fresh summers and the absence of dry seasons, according to the Köppen climate classification (MAAK, 1968). Guarapuava is located at an altitude of 1,098 m.a.s.l. (IPARDES, 2018) and has an annual average rainfall of $1684.7 \mathrm{~mm}$ (SALTON et al., 2016). These conditions create a favorable microclimate for the maintenance of the tick $A$. aureolatum, which is typical of the Atlantic Forest and is described in localities at altitudes of 1,000 m.a.s.l., with rainy temperate climates characterized by mean temperatures ranging from $18{ }^{\circ} \mathrm{C}$ to $22^{\circ} \mathrm{C}$ throughout the year and an annual rainfall of over $1,200 \mathrm{~mm}$ (RODRIGUES et al., 2002; PINTER et al., 2004). Although these conditions prove unfavorable for the other tick species that are vectors of pathogens that can infect dogs in Brazil, climate changes may also be responsible for affecting the interactions that result in the transmission of tick-borne agents (GRAY et al., 2009). Furthermore, it should be noted that an increase in tick prevalence and distribution limits depends not only on the absence of climatic stress but also on animal management conditions, especially when it comes to the tick species $R$. sanguineus (GRAY et al., 2013). Thus, studying and monitoring the occurrence of hemoparasites and their possible transmission vectors are essential to shed light on the epidemiology of these diseases that affect dogs in the midwestern region of the state of Paraná, Brazil.

\section{Conclusions}

The findings of this study revealed the presence of Rangelia vitalii, Babesia vogeli and Hepatozoon canis in dogs living in the city of Guarapuava, midwestern Paraná, Brazil, based on molecular techniques and phylogenetic analysis. These agents have been detected in other regions of the country, but this is the first description of the study area. These pathogens should be included in the differential diagnosis of dogs with clinical signs and hematologic abnormalities suggestive of tick-borne diseases in the city of Guarapuava, Paraná. Lastly, further studies are needed to pinpoint the main vector of these pathogens in the region.

\section{References}

Altschul SF, Gish W, Miller W, Myers EW, Lipman DJ. Basic local alignment search tool. J Mol Biol 1990; 215(3): 403-410. http://dx.doi. org/10.1016/S0022-2836(05)80360-2. PMid:2231712.

Alvarado-Rybak M, Solano-Gallego L, Millán J. A review of piroplasmid infections in wild carnivores worldwide: importance for domestic animal health and wildlife conservation. Parasit Vectors 2016; 9(1): 538. http:// dx.doi.org/10.1186/s13071-016-1808-7. PMid:27724937.
André MR, Adania CH, Teixeira RH, Vargas GH, Falcade M, Sousa L, et al. Molecular detection of Hepatozoon spp. in Brazilian and exotic wild carnivores. Vet Parasitol 2010; 173(1-2): 134-138. http://dx.doi. org/10.1016/j.vetpar.2010.06.014. PMid:20630658.

André MR, Herrera HM, Fernandes SJ, Sousa KC, Gonçalves LR, Domingos $\mathrm{IH}$, et al. Tick-borne agents in domesticated and stray cats from the city of Campo Grande, state of Mato Grosso do Sul, midwestern Brazil. Ticks Tick Borne Dis 2015; 6(6): 779-786. http://dx.doi.org/10.1016/j. ttbdis.2015.07.004. PMid:26187416.

Castro MB, Machado RZ, Aquino LPTC, Alessi AC, Costa MT. Experimental acute canine monocytic ehrlichiosis: clinicopathological and immunopathological findings. Vet Parasitol 2004; 119(1): 73-86. http://dx.doi.org/10.1016/j.vetpar.2003.10.012. PMid:15036578.

Dagnone AS, Souza AI, André MR, Machado RZ. Molecular diagnosis of Anaplasmataceae organisms in dogs with clinical and microscopical signs of ehrlichiosis. Rev Bras Parasitol Vet 2009; 18(4): 20-25. http:// dx.doi.org/10.4322/rbpv.01804004. PMid:20040204.

Dantas-Torres F, Chomel BB, Otranto D. Ticks and tick-borne diseases: a One Health perspective. Trends Parasitol 2012; 28(10): 437-446. http:// dx.doi.org/10.1016/j.pt.2012.07.003. PMid:22902521.

Dantas-Torres F, Otranto D. Best practices for preventing vector-borne diseases in dogs and humans. Trends Parasitol 2016; 32(1): 43-55. http:// dx.doi.org/10.1016/j.pt.2015.09.004. PMid:26507152.

Dantas-Torres F. The brown dog tick, Rhipicephalus sanguineus (Latreille, 1806) (Acari: Ixodidae): from taxonomy to control. Vet Parasitol 2008; 152(3-4): 173-185. http://dx.doi.org/10.1016/j.vetpar.2007.12.030. PMid:18280045.

Darriba D, Taboada GL, Doallo R, Posada D. jModelTest 2: more models, new heuristics and parallel computing. Nat Methods 2012; 9(8): 772. http://dx.doi.org/10.1038/nmeth.2109. PMid:22847109.

Demoner LC, Rubini AS, Paduan KS, Metzger B, Antunes JMAP, Martins TF, et al. Investigation of tick vectors of Hepatozoon canis in Brazil. Ticks Tick Borne Dis 2013; 4(6): 542-546. http://dx.doi.org/10.1016/j. ttbdis.2013.07.006. PMid:24209494.

Doyle CK, Labruna MB, Breitschwerdt EB, Tang Y, Corstvet RE, Hegarty BC, et al. Detection of medically important Ehrlichia by quantitative multicolor TaqMan Real-Time Polymerase Chain Reaction of the $d s b$ gene. J Mol Diagn 2005; 7(4): 504-510. http://dx.doi.org/10.1016/ S1525-1578(10)60581-8. PMid:16237220.

Ewing B, Green P. Base-calling of automated sequencer traces using phred. II. Error probabilities. Genome Res 1998; 8(3): 186-194. http:// dx.doi.org/10.1101/gr.8.3.186. PMid:9521922.

Ewing B, Hillier L, Wendl M, Green P. Base-calling of automated sequencer traces using phred. I. Accuracy assessment. Genome Res 1998; 8(3): 175-185. http://dx.doi.org/10.1101/gr.8.3.175. PMid:9521921.

Felsenstein J. Confidence limits on phylogenies: an approach using the bootstrap. Evolution 1985; 39(4): 783-791. http://dx.doi. org/10.1111/j.1558-5646.1985.tb00420.x. PMid:28561359.

Fighera RA, Souza TM, Kommers GG, Irigoyen LF, Barros CSL. Pathogenesis, clinical, hematological, and pathological aspects of Rangelia vitalii infection in 35 dogs (1985-2009). Pesq Vet Bras 2010; 30(11): 974-987. http://dx.doi.org/10.1590/S0100-736X2010001100012.

Fighera RA. Rangeliosis. Acta Sci Vet 2007; 35(Supl. 2): 261-263.

Forlano M, Scofield A, Elisei C, Fernandes KR, Ewing SA, Massard CL. Diagnosis of Hepatozoon spp. in Amblyomma ovale and its experimental 
transmission in domestic dogs in Brazil. Vet Parasitol 2005; 134(1-2): 1-7. http://dx.doi.org/10.1016/j.vetpar.2005.05.066. PMid:16081219.

Forlano MD, Teixeira KR, Scofield A, Elisei C, Yotoko KS, Fernandes $\mathrm{KR}$, et al. Molecular characterization of Hepatozoon sp. from Brazilian dogs and its phylogenetic relationship with other Hepatozoon spp. Vet Parasitol 2007; 145(1-2): 21-30. http://dx.doi.org/10.1016/j.vetpar.2006.10.023. PMid:17134837.

França RT, Silva AS, Loretti AP, Mazzanti CM, Lopes ST. Canine rangeliosis due to Rangelia vitalii: from first report in Brazil in 1910 to current day - a review. Ticks Tick Borne Dis 2014; 5(5): 466-474. http:// dx.doi.org/10.1016/j.ttbdis.2014.04.005. PMid:24950853.

França RT, Silva AS, Paim FC, Costa MM, Soares JF, Mazzanti CM, et al. Rangelia vitalii in dogs in Southern Brazil. Comp Clin Pathol 2010; 19(4): 383-387. http://dx.doi.org/10.1007/s00580-010-1041-2.

Giannelli A, Ramos RA, Di Paola G, Mencke N, Dantas-Torres F, Baneth $\mathrm{G}$, et al. Transstadial transmission of Hepatozoon canis from larvae to nymphs of Rhipicephalus sanguineus. Vet Parasitol 2013; 196(1-2): 1-5. http://dx.doi.org/10.1016/j.vetpar.2013.02.017. PMid:23537949.

Gomes LA, Moraes PH, Nascimento LC, O’Dwyer LH, Nunes MR, Rossi AD, et al. Molecular analysis reveals the diversity of Hepatozoon species naturally infecting domestic dogs in a northern region of Brazil. Ticks Tick Borne Dis 2016; 7(6): 1061-1066. http://dx.doi.org/10.1016/j. ttbdis.2016.09.008. PMid:27665264.

Gray J, Dantas-Torres F, Estrada-Peña A, Levin M. Systematics and ecology of the brown dog tick, Rhipicephalus sanguineus. Ticks Tick Borne Dis 2013; 4(3): 171-180. http://dx.doi.org/10.1016/j.ttbdis.2012.12.003. PMid:23415851.

Gray JS, Dautel H, Estrada-Peña A, Kahl O, Lindgren E. Effects of climate change on ticks and tick-borne diseases in Europe. Interdiscip Perspect Infect Dis 2009; 2009: 593232. http://dx.doi.org/10.1155/2009/593232. PMid:19277106.

Hall TA. BioEdit: a user-friendly biological sequence alignment editor and analysis program for Windows 95/98/NT. Nucleic Acids Symp Ser 1999; 41: 95-98.

Harrus S, Baneth G. Drivers for the emergence and re-emergence of vector-borne protozoal and bacterial diseases. Int J Parasitol 2005; 35(11-12): 1309-1318. http://dx.doi.org/10.1016/j.ijpara.2005.06.005. PMid:16126213.

Instituto Paranaense de Desenvolvimento Econômico Social - IPARDES. Caderno estatístico municipio de Guarapuava [online]. Curitiba: IPARDES; 2018 [cited 2017 Sep 01]. Available from: http://www.ipardes.gov.br/ cadernos/MontaCadPdf1.php?Municipio=85000

Jefferies R, Ryan UM, Irwin PJ. PCR-RFLP for the detection and differentiation of the canine piroplasm species and its use with filter paper-based technologies. Vet Parasitol 2007; 144(1-2): 20-27. http:// dx.doi.org/10.1016/j.vetpar.2006.09.022. PMid:17127005.

Kuttler KL. Canine babesiosis. In: Ristic M, editor. Babesiosis of domestic animals and man. Boca Raton: CRC Press; 1988. p. 12-13.

Lappin MR. Update on the diagnosis and management of Hepatozoon spp. infections in dogs in the United States. Top Companion Anim Med 2010; 25(3): 142-144. http://dx.doi.org/10.1053/j.tcam.2010.07.004. PMid:20937496.

Lemos TD, Cerqueira AMF, Toma HK, Silva AV, Corrêa RGB, Paludo GR, et al. Detection and molecular characterization of piroplasms species from naturally infected dogs in southeast Brazil. Rev Bras Parasitol Vet 2012;
21(2): 137-142. http://dx.doi.org/10.1590/S1984-29612012000200012. PMid:22832754.

Lemos TD, Toma HK, Assad RQ, Silva AV, Corrêa RGB, Almosny NRP. Clinical and hematological evaluation of Rangelia vitalii-naturally infected dogs in southeastern Brazil. Rev Bras Parasitol Vet 2017; 26(3): 307-313. http://dx.doi.org/10.1590/s1984-29612017040. PMid:28902259.

Loretti AP, Barros SS. Parasitism by Rangelia vitalii in dogs ("Nambiuvú", "Peste De Sangue") - a critical review on the subject. Arq Inst Biol 2004; 71(1): 101-131.

Maak R. Geografia física do Estado do Paraná. Curitiba: Banco de Desenvolvimento do Estado do Paraná; 1968. 350 p.

Malheiros J, Costa MM, Amaral RB, Sousa KCM, Andre MR, Machado $\mathrm{RZ}$, et al. Identification of vector-borne pathogens in dogs and cats from Southern Brazil. Ticks Tick Borne Dis 2016; 7(5): 893-900. http://dx.doi. org/10.1016/j.ttbdis.2016.04.007. PMid:27266811.

Melo AL, Witter R, Martins TF, Pacheco TA, Alves AS, Chitarra CS, et al. A survey of tick-borne pathogens in dogs and their ticks in the Pantanal biome, Brazil. Med Vet Entomol 2016; 30(1): 112-116. http://dx.doi. org/10.1111/mve.12139. PMid:26467462.

Miller MA, Pfeiffer W, Schwartz T. Creating the CIPRES science gateway for inference of large phylogenetic trees [online]. 2010 [cited 2010 Nov 14]. Available from http://ieeexplore.ieee.org/stamp/stamp.jsp?arnumber=5676129

Moraes-Filho J, Krawczak FS, Costa FB, Soares JF, Labruna MB. Comparative evaluation of the vector competence of four south american populations of the Rhipicephalus sanguineus group for the bacterium Ehrlichia canis, the agent of canine monocytic ehrlichiosis. PLoS One 2015; 10(9): e0139386. http://dx.doi.org/10.1371/journal.pone.0139386. PMid:26414283.

Mundim AV, Morais IA, Tavares M, Cury MC, Mundim MJ. Clinical and hematological signs associated with dogs naturally infected by Hepatozoon sp. and with other hematozoa: a retrospective study in Uberlândia, Minas Gerais, Brazil. Vet Parasitol 2008; 153(1-2): 3-8. http://dx.doi. org/10.1016/j.vetpar.2008.01.018. PMid:18304739.

Nakaghi ACH, Machado RZ, Costa MT, André MR, Baldani CD. Canine ehrlichiosis: clinical, hematological, serological and molecular aspects. Cienc Rural 2008; 38(3): 766-770. http://dx.doi.org/10.1590/ S0103-84782008000300027.

Nakaghi ACH, Machado RZ, Ferro AP, Labruna MB, Chryssafidis AL, Andre MR, et al. Sensitivity evaluation of a single-step PCR assay using Ehrlichia canis $p 28$ gene as a target and its application in diagnosis of canine ehrlichiosis. Rev Bras Parasitol Vet 2010; 19(2): 75-79. http:// dx.doi.org/10.1590/S1984-29612010000200001. PMid:20624341.

Nava S, Estrada-Peña A, Petney T, Beati L, Labruna MB, Szabó MPJ, et al. The taxonomic status of Rhipicephalus sanguineus (Latreille, 1806). Vet Parasitol 2015; 208(1-2): 2-8. http://dx.doi.org/10.1016/j. vetpar.2014.12.021. PMid:25560924.

O’Dwyer LH, Massard CL, Souza JCP. Hepatozoon canis infection associated with dog ticks of rural areas of Rio de Janeiro State, Brazil. Vet Parasitol 2001; 94(3): 143-150. http://dx.doi.org/10.1016/S03044017(00)00378-2. PMid:11113545.

O’Dwyer LH, Moço TC, Paduan KS, Spenassatto C, Silva RJ, Ribolla PE. Description of three new species of Hepatozoon (Apicomplexa, Hepatozoidae) from Rattlesnakes (Crotalus durissus terrificus) based on molecular, morphometric and morphologic characters. Exp Parasitol 2013 135(2): 200-207. http://dx.doi.org/10.1016/j.exppara.2013.06.019. PMid:23867148. 
O’Dwyer LH. Brazilian Canine Hepatozoonosis. Rev Bras Parasitol Vet 2011; 20(3): 181-193. http://dx.doi.org/10.1590/S1984-29612011000300002. PMid:21961746.

Paim CB, Paim FC, Silva AS, França RT, Costa MM, Leal CA, et al. Thrombocytopenia and platelet activity in dogs experimentally infected with Rangelia vitalii. Vet Parasitol 2012; 185(2-4): 131-137. http://dx.doi. org/10.1016/j.vetpar.2011.09.039. PMid:22019200.

Passos LM, Geiger SM, Ribeiro MF, Pfister K, Zahler-Rinder M. First molecular detection of Babesia vogeli in dogs from Brazil. Vet Parasitol 2005; 127(1): 81-85. http://dx.doi.org/10.1016/j.vetpar.2004.07.028. PMid:15619377.

Pereira AM, Cerqueira AMF, Velho PB, Sá AG, Ferreira RF, Macieira $\mathrm{DB}$, et al. Occurrence of Hepatozoon spp. in naturally infected dogs from Piraí, Rio de Janeiro, Brazil. R Bras Ci Vet 2011; 18(2-3): 121-125.

Perkins SL, Keller AK. Phylogeny of nuclear small subunit rRNA genes of hemogregarines amplified with specific primers. J Parasitol 2001; 87(4): 870-876. http://dx.doi.org/10.1645/0022-3395(2001)087[0870:PON SSR]2.0.CO;2. PMid:11534653.

Pinter A, Dias RA, Gennari SM, Labruna MB. Study of the seasonal dynamics, life cycle, and host specificity of Amblyomma aureolatum (Acari: Ixodidae). J Med Entomol 2004; 41(3): 324-332. http://dx.doi. org/10.1603/0022-2585-41.3.324. PMid:15185932.

Posada D, Buckley TR. Model selection and model averaging in phylogenetics: advantages of akaike information criterion and bayesian approaches over likelihood ratio tests. Syst Biol 2004; 53(5): 793-808. http://dx.doi.org/10.1080/10635150490522304. PMid:15545256.

Rikihisa Y. Diagnosis of canine monocytic ehrlichiosis: development of advanced techniques to combat a global disease. Vet J 2011; 187(3): 285-286. http://dx.doi.org/10.1016/j.tvjl.2010.05.031. PMid:20580578.

Rodrigues DS, Carvalho HA, Fernandes AA, Freitas CMV, Leite RC, Oliveira PR. Biology of Amblyomma aureolatum (Pallas, 1772) (Acari: Ixodidae) on some laboratory hosts in Brazil. Mem Inst Oswaldo Cruz 2002; 97(6): 853-856. http://dx.doi.org/10.1590/S0074-02762002000600018. PMid:12386709.

Ronquist F, Huelsenbeck JP. MrBayes 3: Bayesian phylogenetic inference under mixed models. Bioinformatics 2003; 19(12): 1572-1574. http:// dx.doi.org/10.1093/bioinformatics/btg180. PMid:12912839.

Rubini AS, Paduan KS, Cavalcante GG, Ribolla PEM, O’Dwyer LH. Molecular identification and characterization of canine Hepatozoon species from Brazil. Parasitol Res 2005; 97(2): 91-93. http://dx.doi.org/10.1007/ s00436-005-1383-x. PMid:15948009.

Salton FG, Morais H, Caramori PH, Borrozzino E. Climatologia dos Episódios de Precipitação em Três Localidades no Estado do Paraná. Rev Bras Meteorol 2016; 31(4): 626-638. http://dx.doi.org/10.1590/0102$7786312314 \mathrm{~b} 20150108$.

Sanches GS, Évora PM, Mangold AJ, Jittapalapong S, Rodriguez-Mallon A, Guzmán PE, et al. Molecular, biological, and morphometric comparisons between different geographical populations of Rhipicephalus sanguineus sensu lato (Acari: Ixodidae). Vet Parasitol 2016; 215: 78-87. http://dx.doi. org/10.1016/j.vetpar.2015.11.007. PMid:26790741.
Sanger F, Nicklen S, Coulson AR. DNA sequencing with chain-terminating inhibitors. Proc Natl Acad Sci USA 1977; 74(12): 5463-5467. http:// dx.doi.org/10.1073/pnas.74.12.5463. PMid:271968.

Soares JF, Girotto A, Brandão PE, Silva AS, França RT, Lopes STA, et al. Detection and molecular characterization of a canine piroplasm from Brazil. Vet Parasitol 2011; 180(3-4): 203-208. http://dx.doi.org/10.1016/j. vetpar.2011.03.024. PMid:21489694.

Soares JF, Girotto-Soares A. Rangeliose. In: Ribeiro CM, editor. Enfermidades parasitárias por protozoários em pequenos animais. Rio de Janeiro: Rubio; 2015. p. 93-102.

Sousa KC, Fernandes MP, Herrera HM, Benevenute JL, Santos FM, Rocha FL, et al. Molecular detection of Hepatozoon spp. in domestic dogs and wild mammals in southern Pantanal, Brazil with implications in the transmission route. Vet Parasitol 2017; 237: 37-46. http://dx.doi. org/10.1016/j.vetpar.2017.02.023. PMid:28291601.

Sousa KCM, Andre MR, Herrera HM, Andrade GB, Jusi MMG, Santos LL, et al. Molecular and serological detection of tick-borne pathogens in dogs from an area endemic for Leishmania infantum in Mato Grosso do Sul, Brazil. Rev Bras Parasitol Vet 2013; 22(4): 525-531. http://dx.doi. org/10.1590/S1984-29612013000400012. PMid:24473877.

Spolidorio MG, Labruna MB, Zago AM, Donatele DM, Caliari K, Yoshinari NH. Hepatozoon canis infecting dogs in the State of Espírito Santo, southeastern Brazil. Vet Parasitol 2009; 163(4): 357-361. http:// dx.doi.org/10.1016/j.vetpar.2009.05.002. PMid:19482427.

Spolidorio MG, Torres MM, Campos WNS, Melo ALT, Igarashi M, Amude AM, et al. Molecular detection of Hepatozoon canis and Babesia canis vogeli in domestic dogs from Cuiabá, Brazil. Rev Bras Parasitol Vet 2011; 20(3): 253-255. http://dx.doi.org/10.1590/S1984-29612011000300015. PMid:21961759.

Stöver BC, Muller KF. TreeGraph 2: combining and visualizing evidence from different phylogenetic analyses. BMC Bioinformatics 2010; 11(1): 7. http://dx.doi.org/10.1186/1471-2105-11-7. PMid:20051126.

Szabó MP, Mangold AJ, João CF, Bechara GH, Guglielmone AA. Biological and DNA evidence of two dissimilar populations of the Rhipicephalus sanguineus tick group (Acari: Ixodidae) in South America. Vet Parasitol 2005; 130(1-2): 131-140. http://dx.doi.org/10.1016/j.vetpar.2005.03.008. PMid:15893080.

Thompson JD, Higgins DG, Gibson TJ. Clustal W: improving the sensitivity of progressive multiple sequence alignment through sequence weighting, position-specific gap penalties and weight matrix choice. Nucleic Acids Res 1994; 22(22): 4673-4680. http://dx.doi.org/10.1093/ nar/22.22.4673. PMid:7984417.

Trapp SM, Messick JB, Vidotto O, Jojima FS, Morais HS. Babesia gibsoni genotype Asia in dogs from Brazil. Vet Parasitol 2006; 141(1-2): $177-$ 180. http://dx.doi.org/10.1016/j.vetpar.2006.04.036. PMid:16765518.

Trifinopoulos J, Nguyen LT, Von Haeseler A, Minh BQ. W-IQ-TREE: a fast online phylogenetic tool for maximum likelihood analysis. Nucleic Acids Res 2016; 44(W1): 232-235. http://dx.doi.org/10.1093/nar/ gkw256. PMid:27084950.

Ujvari B, Madsen T, Olsson M. High prevalence of Hepatozoon spp. (Apicomplexa, Hepatozoidae) infection in water pythons (Liasis fuscus) from tropical Australia. J Parasitol 2004; 90(3): 670-672. http://dx.doi. org/10.1645/GE-204R. PMid:15270125. 